\title{
Do We Experience Misconceptions?: An Ontological Review of Misconceptions in Science
}

\author{
${ }^{*} \mathbf{N}$ Suprapto ${ }^{1}$ \\ ${ }^{1}$ Department of Physics, Faculty of Mathematics and Natural Science, Universitas Negeri Surabaya, Surabaya 60231, \\ Indonesia
}

\begin{tabular}{l}
\hline Article Info \\
\hline Article history: \\
Received April 2, 2020 \\
Revised April 18, 2020 \\
Accepted April 20, 2020 \\
Available Online April 20, 2020 \\
\hline
\end{tabular}

Keywords:

Misconception

Types

Science

Physics

\begin{abstract}
A misconception is a misunderstanding in connecting a concept with other concepts, between new concepts and old concepts that are already in the minds of students, so that the wrong concepts are formed. Students' conceptions are different or contrary to the conceptions of the scientists. There are five kinds of misconceptions, namely: (a) preconceived notions; (b) non-scientific beliefs; (c) conceptual misunderstandings; (d) misconceptions of local languages (vernacular misconceptions); and (e) factual misconceptions. The causes of misconceptions are four parts: students, teachers, teaching materials or literature, context and teaching methods. It is expected that by knowing the types and causes of students' misconceptions in understanding science, it will be easier for teachers to find solutions in teaching science concepts. Examples of data related to misconceptions in physics are illustrated to reinforce explanations.
\end{abstract}

\section{INTRODUCTION}

Everyone can experience misconception, not only students experience it, but it also is experienced by adults, including teachers, lecturers, and even professors. A misconception is a misunderstanding in connecting a concept with other concepts, between new concepts and old concepts that are already in the minds of students, so that the wrong concepts are formed.

Misconceptions are often found in the field of science. Indeed, they occur in all physics concepts. Of the 700 investigations regarding misconceptions, 300 that examined mechanics, 159 about electricity, 70 about heat, optics, and the properties of materials, 35 about earth and space, and about modern physics (Suparno, 2005; Wandersee, Mintzes, \& Novak, 1994). An investigation conducted by Maharta (2009) about the physics misconception of senior high school students in Bandar Lampung shows that the level of physics misconceptions of students is very high at $65 \%$. The results of a study of the national examination in $2007 / 2008$ by the Educational Quality Assurance Agency in DKI Jakarta province on the physics subjects showed that: (1) electromagnetic is 49.62 fewer categories; (2) optics are 51.04 fewer categories; (3) mechanics are 59.68 fewer categories; (4) wave 60.55 enough categories; (5) modern physics is 62.84 enough categories and (6) thermodynamics are 68.69 enough categories (LPMP DKI Jakarta, 2011). The results of the investigation show the concept of Mechanics is included in the category of lack and difficulty in the concept of Mechanics.

Students who lack an understanding of mathematics will affect their understanding of physics. Misconceptions can also occur due to errors from teaching materials. Written mistakes will be easily digested by students, and thus they will get misconceptions (Lambi, 2009; 
Suparno, 2005). This review provides a foundation to find out the types of misconceptions that occur in students and the causes of students' misconceptions about science.

Having experiences in research on misconceptions, see (Jauhariyah, Suprapto, Suliyanah, Admoko, Setyarsih, Harizah, \& Zulfa, 2018; Suprapto, Abidah, Dwiningsih, Jauhariyah, Saputra, 2018; Suprapto, Syahrul, Agustihana, Pertiwi, \& Ku, 2016), the author tries to present the ontological review of misconceptions in science in this editorial. "Ontology is the philosophical study of being - it studies concepts that directly relate to being, in particular becoming, existence, reality, as well as the basic categories of being and their relations" (Merriam-webster, 2020). The focus of this review is addressed into two questions: 1. What types of misconceptions occur in students learning science? 2. What are the causes of science misconceptions on students?. The benefits of this discussion are as follows. The problem faced by the world of education today, especially in Indonesia is the quality of science teachers who are still lacking, learning facilities and infrastructure (teaching materials, laboratory equipment, and learning media) are very limited, even still lacking science teachers. By knowing the types of misconceptions and the causes of students' misconceptions, it can help science teachers who have taught in Indonesia in general, to think of an appropriate approach to improve misconceptions and improve the achievement of student learning outcomes, attitudes and mathematical mastery of science because teachers are an important asset in efforts to improve education to a higher stage.

The misinterpretation of concepts or popular calls for misconception, found in the fields of science or other social fields, was investigated in the early 80 s and has been at the core of empirical research in learning science for the past 20 years (Gonen \& Kocakaya, 2006). Various terms have been used by educational experts relating to misconceptions (Alparslan, Tekkaya, \& Geban, 2003; Hammer, 1996; Smith, diSessa, \& Roschelle, 1994; Suprapto et al, 2018, 2019).

The first type of misconception is called "preconceived notions" (Brown \& Clement, 1991; CUSE-NRC, 1997; Marshall 2003). This type of misconception is a conception that is often based on everyday experience, both those around the school or outside the school environment. When someone enters school, he will receive a scientific explanation that is not intuitive about what he saw in the past (CUSE, 1997). It turns out that understanding the initial concepts has caused difficulties for students to understand the concepts of heat, energy, and gravity (Brown \& Clement, 1991; CUSE, 1997). Many experts see this type of misconception more excessive than necessary, but students prefer it because it seems more rational (CUSE, 1997). Confidence in the initial conceptual understanding remains unchanged even after the teaching \& learning process has been carried out; therefore it is a cause for the learning process (CUSE, 1997; McDermott, 1991).

The second type of misconception is called "non-scientific beliefs" (CUSE, 1997). Unscientific beliefs are all views learned by students rather than sources that differ from the opinions of experts. One method that emerges is mythical or religious teaching in which there is no scientific proof of truth. Evolution and the Big Bang are two theories, one that is incompatible with the concept of religion and the second is in accordance with religious views (Podolner, 2000).

The third misconception is called 'conceptual misunderstandings'. Typically this type of misconception arises when students relate to expert opinions in a way that does not cause students to resolve paradoxes or conflicts due to the presumption of initial concepts and unscientific beliefs (CUSE, 1997). Students end learning with a feeling of dissatisfaction and not being able to explain what they have learned. As a result, these students build wrong models that limit the educational process in the future (Podolner, 2000).

The fourth misconception is called local language misconception or vernacular misconceptions (CUSE, 1997; Marshall 2003), which arises from the use of words that mean something to many people who are not experts, the same thing will be very different when discussed from a scientific point of view. 
The fifth type of misconception called 'factual misconceptions' are mistakes that occur in childhood and remain unchanged until adulthood (CUSE, 1997; Marshall, 2003). Parents, teachers, and even textbooks may be the main cause of this error. Their own textbooks can be a mistake in the spread of misconceptions. Many famous scientists noted that they could not help to solve this. The famous physicist and Nobel Prize winner (Richard Feynman) has noted that all the books are there: they say something that is useless, confusing, vague, erroneous and only partially correct.

There are many ways that misconception can occur. Scientific data constantly changes over time. No one can keep up with all the latest information findings, meaning that everyone will be impressed with changes in information from time to time. As a teacher should teach good and current information; however, during a textbook written and published, some of the information is outdated. Inability to stay up to date or inability to keep abreast of information changes from time to time causes misunderstanding of information (Lambi, 2009). Not only to the extent of misinformation but also contradictions of information occur, because of conflicting views. Conflicting information confuses and can lead to the merging of information in the form of new, more intricate concepts or misconceptions. Teachers sometimes continue their misconceptions through teaching, giving a concept that is contrary to the scientific concept (Lambi, 2009; Marshall, 2003).

\section{RESULTS AND DISCUSSION}

Meanwhile, causes of misconceptions can be grouped into four parts, namely students, teachers, teaching materials or literature, context and teaching methods (Suparno, 2009).

\section{a. Students}

Students misconceptions in the field of science most come from students themselves. Misconceptions originating from students can be collected in several ways, namely initial knowledge or preconceptions or prior knowledge, associative thinking of students, humanistic thinking, incomplete or wrong reasoning, wrong intuition, stages of student cognitive development, student ability, and student interest (Suparno, 2005).

(i) Initial knowledge

Many students have already an initial concept or preconception or prior knowledge about a concept before students take formal lessons under the guidance of the teacher. This initial concept often contained misconceptions. This initial misconception will cause misconceptions when taking physics lessons onward until the error is corrected (Berg, 1991; Chi, 2008; Suparno, 2005).

(ii) Students 'associative thinking

Students' associations of everyday terms sometimes also create misconceptions (Suparno, 2005). For example, students associate 'style' with force or displacement. Force is considered by many students to always cause displacement. If students don't see a moving object, they make sure there is no force. Even though physics is not always true, for example, some students remain convinced that there is no force on a train driven by people because the train is still stopping. The truth is, the train is still going on force, only the force is not strong enough to move the train. Different understanding from words between students and teachers can also cause misconceptions (Marshall \& Gilmour, 1990).

(iii) Humanistic thinking

Students often look at things from a human perspective. Objects and situations are thought about in people's experiences and humanly. The behavior of things is understood as the behavior of living humans so it does not fit.

(iv) Incomplete or wrong reasoning

Misconceptions can also be caused by students' incomplete or incorrect reasoning or reasoning. Incomplete reasons can be caused by the information obtained or the data obtained is 
incomplete. As a result, students draw wrong conclusions and this leads to student misconceptions.

(v) False intuition

False intuition and student feelings can also cause misconceptions. Intuition is a feeling in someone who spontaneously expresses his attitude or ideas about something before being researched objectively and rationally. Intuitive thinking or understanding usually comes from observations of objects or events that continue to occur, eventually spontaneously when faced with certain physics problems that arise in the minds of students is that spontaneous understanding.

(vi) Stages of students' cognitive development

Students' cognitive development that is not in accordance with the material occupied by them may be the cause of students' misconceptions. In general, students who are still in the concrete operational stage when learning an abstract material are difficult to catch and often misunderstand the concept of the material.

(vii) Students' abilities

Students who are less gifted in physics or less able to understand physics often have difficulty capturing the correct concepts in the learning process.

(viii) Learning Interest

Students who are not interested in physics, are usually less interested in learning physics and pay less attention to the teacher's explanation of the new understanding of physics.

\section{b. Teachers}

Teachers who do not master the material or understand physics material incorrectly will cause students to get misconceptions. Some physics teachers themselves do not understand physics concepts very well, so this misunderstanding is passed on to students (Chiu, Guo, \& Treagust, 2007; Simanek, 2007). According to Suparno (2005) teachers' misconceptions are caused by teachers not mastering subject matter, not graduates from the field of physics, do not provide opportunities for students to express their ideas, and teacher relations with students are not good.

\section{c. Textbooks and literature}

Textbooks are an inseparable part of learning and the specific curriculum of physics and play a very important role in shaping physics learning as it is now. In the learning process, teachers and students are never separated from textbooks and literature. Textbooks that are used as the only source of guidance for teachers will encourage misconceptions among teachers (Lambi, 2009; Simanek, 2007). Textbooks that express the wrong concept will confused students and also develop students' misconceptions. So, it is important that the textbooks are properly researched.

\section{d. Teaching methods}

Several teaching methods are used by teachers, especially those that emphasize only one aspect of the concept of the material being worked on, even though they help students understand the material being taught, but often have a negative impact, which raises student misconceptions. So the teacher needs to be critical with the method used and not limit it with just one method (Suparno, 2005).

\section{REFERENCES}

Alparslan, C., Tekkaya, C., \& Geban, O. (2003). Using the conceptual change instruction to improve learning. Journal of Education, 37, 133-137.

Berg, E. Van den. (1991). Miskonsepsi fisika dan remediasi. Salatiga: Universitas Kristen Satya Wacana. 
Brown, D. E., \& Clement, J. (1991). Overcoming misconceptions via analogical reasoning: Factors influencing understanding in a teaching experiment. Instructional Science, 18, 237261.

Chi, M. T. H. (2008). Three types of conceptual change: Belief revision, mental model transformation, and categorical shift. In. S. Vosniadou (Ed), Handbook of research on conceptual change (pp.61-82). New York, NY: Routledge.

Chiu, M. H., Guo, C. J., \& Treagust, D. F. (2007). Assessing student' conceptual understanding in science: An introduction about a national project in Taiwan. International Journal of Science Education, 29(4), 379-390.

CUSE. (1997). Comittee on Undergraduate Science Education and National Research Council. National Research Council: National Academies Press.

Gonen, S., \& Kocakaya, S. (2006). Physics teachers' opinions on physics instructional activities and content of physics textbooks. Journal of Turkish Science education, 3, 40-42.

Hammer, D. (1996). Misconceptions or P-Prims: How may alternative perspectives of cognitive structure influence instructional perceptions and intentions? The Journal of the learning Sciences, 5, 97-127.

Jauhariyah, M. N. R., Suprapto, N., Suliyanah, Admoko, S., Setyarsih, W., Harizah, Z., Zulfa, I. (2018). The Students' misconceptions profile on chapter gas kinetic theory. Journal of Physics: Conference Series, 997(1), 012031.

LPMP. (2011). Laporan penelitian Lembaga Penjamin Mutu Pendidikan Provinsi DKI Jakarta, 2011. Tidak dipublikasikan.

Lambi, E. A. (2009). A case study on the use of a formative assesment probe to determine the presence of science misconception in elementary school students: Implications for teaching and curriculum. Unpublished Doctoral Dissertation. Widener University.

Maharta, N. (2009). Analisis miskonsepsi fisika siswa SMA Bandar Lampung. Laporan penelitian (Unpublished). PMIPA, FKIP Univ. Lampung.

Marshall, H. A. (2003). Countering astronomy misconceptions in high school students, In partial fulfilment of SCE 5305 the University of Texas at Dallas April 28.

Marshall, S., \& Gilmour, M. (1990). Problematical words and concepts in physics education: A study of Papua New Guinean students' comprehension of non-technical word used in science. Physics Education, 25(6), 330-337.

McDermott. (1991). What we teach and what is learned: Closing the gap. American Journal of Physics, 59(4), 301-305.

Merriam-webster. (2020). Ontology. Retrieved from https://www.merriamwebster.com/dictionary/ontology.

Podolner, A. S. (2000). Eradicating physics misconceptions using the conceptual change method, Department of Education Kalamazoo College Kalamazoo, Michigan.

Simanek, D. E. (2008). The dangers of analogies. Retrieved from http://www.lhup.edu/ dsimanek/scenorio/miscon.htm

Smith, J. P., diSessa, A. A., \& Roschelle, J. (1994). A constructivist analysis of knowledge in transition. Journal of the Learning Sciences, 3, 115-163.

Suparno, P. (2005). Miskonsepsi \& perubahan konsep fisika. Jakarta: Grasindo.

Suprapto, N., Abidah, A., Dwiningsih, K., Jauhariyah, M.N.R., Saputra, A. (2018). Minimizing misconception of ionization energy through three-tier diagnostic test. Periodico Tche Quimica,15 (30), 387-396.

Suprapto, N., Syahrul, D.A., Agustihana, S., Pertiwi, C.A., \& Ku, C.-H. (2016). College students' conceptions of Newtonian mechanics: A case of Surabaya State University Indonesia. Chemistry, 25(5), 718-731.

Wandersee, J. H., Mintzes, J. J., \& Novak, D. (1994). Research on alternative conceptions in science. In: Gabel, D.L., Ed., Handbook of Research on Science Teaching and Learning, Macmillan, New York, 177-210. 
Do We Experience Misconceptions?: An Ontological Review of Misconceptions in Science https://doi.org/10.46627/sipose.v1i2.24

\section{Author:}

* Nadi Suprapto (Corresponding Author)

Department of Physics, Faculty of Mathematics and Natural Science,

Universitas Negeri Surabaya,

Jl. Ketintang, Surabaya 60231, Indonesia

Email: nadisuprapto@gmail.com; editor.siposejournal@gmail. 